\title{
A laminated polymer film formulation for enteric delivery of live vaccine and probiotic bacteria
}

Article

Accepted Version

Manuscript and figures

de Barros, J. M. S., Scherer, T., Charalampopoulos, D., Khutoryanskiy, V. V. and Edwards, A. D. (2014) A laminated polymer film formulation for enteric delivery of live vaccine and probiotic bacteria. Journal of Pharmaceutical Sciences, 103 (7). pp. 2022-2032. ISSN 1520-6017 doi:

https://doi.org/10.1002/jps.23997 Available at https://centaur.reading.ac.uk/36803/

It is advisable to refer to the publisher's version if you intend to cite from the work. See Guidance on citing.

To link to this article DOI: http://dx.doi.org/10.1002/jps.23997

Publisher: Wiley

All outputs in CentAUR are protected by Intellectual Property Rights law, including copyright law. Copyright and IPR is retained by the creators or other copyright holders. Terms and conditions for use of this material are defined in the End User Agreement. 


\section{CentAUR}

Central Archive at the University of Reading

Reading's research outputs online 


\title{
A Laminated Polymer Film Formulation for Enteric Delivery of Live Vaccine and Probiotic Bacteria
}

\author{
Joao M. S. de Barros ${ }^{1}$, Timothy Scherer ${ }^{1}$, Dimitrios Charalampopoulos ${ }^{2}$, \\ Vitaliy V. Khutoryanskiy ${ }^{1}$ and Alexander D. Edwards ${ }^{1} *$ \\ ${ }^{1}$ School of Pharmacy, University of Reading, Whiteknights, Reading RG6 6AD, UK. \\ ${ }^{2}$ Food and Nutritional Sciences, University of Reading, Whiteknights, Reading RG6 6AD, UK. \\ * Corresponding author contact details. Email: a.d.edwards@ reading.ac.uk. Phone <44> 118378 \\ 4253 Fax +44 (0) 1183784703.
}

\begin{abstract}
Live bacterial cells (LBC) are administered orally as attenuated vaccines, to deliver biopharmaceutical agents, and as probiotics to improve gastrointestinal health. However, LBC present unique formulation challenges and must survive gastrointestinal antimicrobial defenses including gastric acid after administration. We present a simple new formulation concept, termed Polymer Film Laminate (PFL). LBC are ambient dried onto cast acid-resistant enteric polymer films that are then laminated together to produce a solid oral dosage form. LBC of a model live bacterial vaccine and a probiotic were dried directly onto a cast film of enteric polymer. The effectiveness at protecting dried cells in a simulated gastric fluid ( $\mathrm{pH} 2.0$ ) depended on the composition of enteric polymer film used, with a blend of ethylcellulose plus Eudragit L100 55 providing greater protection from acid than Eudragit alone. However, although PFL made from blended polymers films completely released low molecular weight dye into intestinal conditions ( $\mathrm{pH}$ 7.0), they failed to release LBC. In contrast, PFL made from Eudragit alone successfully protected dried probiotic or vaccine LBC from simulated gastric fluid for $2 \mathrm{~h}$, and subsequently released all viable cells within 60min of transfer into simulated intestinal fluid. Release kinetics could be controlled by modifying the lamination method.
\end{abstract}

\section{KEYWORDS}

Oral delivery; Enteric delivery; oral vaccines; probiotics; polymer film

\section{ABBREVIATIONS}

TPY broth, Tryptone-Phytone-Yeast broth; LBC, live bacterial cells; SIF, simulated intestinal fluid ( $\mathrm{pH}$ 7.0); SGF, simulated gastric fluid ( $\mathrm{pH} 2.0$ ); CFU, colony forming unit; MLF, multilayer laminated film formulation; TF, thick laminated film formulation; EC, ethylcellulose; PFL, polymer film laminate; DoE, design of experiments. 


\section{Introduction}

Recently there has been a growing need to formulate and deliver increasingly complex biological therapeutics, from peptides, recombinant proteins and monoclonal antibodies to in vitro cultured eukaryotic cells, such as stem cells, and therapeutic live bacterial cells (LBC). Therapeutic LBC are being explored for various applications, each of which requires a tailored formulation in order to be delivered effectively. Attenuated live bacterial vaccines either injected (Bacillus Calmette-Guerin) or oral (Ty21a, Vivotif) can closely mimic natural infection and typically promote potent, long-lasting protective immune responses ${ }^{1}$. Genetically engineered LBC vaccines can deliver heterologous antigens and induce an immune response to both the attenuated strain and the vector, thus protecting against a wide range of infections ${ }^{2}$. Some orally administered therapeutic LBC are classed as probiotics, and are currently under intense development to modulate the gut microbiota in health and disease ${ }^{3,4}$. Commensal enteric bacteria have also been genetically engineered to deliver biopharmaceutical agents such as IL-10 to treat inflammatory bowel disease ${ }^{5}$ or insulinotrophic proteins such as GLP-1 ${ }^{6}$. For all of these fields to advance, oral formulations are needed of LBC that offer the potential for controlled delivery of known doses of viable organisms, maintain stability for long-term storage preferably without refrigeration, and allow cost-effective manufacture.

For LBC to be therapeutically active, cells must be kept alive during formulation and delivery. For example, dead bacteria are less immunogenic than live cells ${ }^{7,8}$, and although some health benefits have been suggested for dead probiotic cells, only live cells can replicate within and colonize the colon ${ }^{9}$. Mammals have evolved a highly antimicrobial gastrointestinal (GI) tract as a defense against food- and water-borne microbial enteric pathogens, and LBC administered by the oral route confront multiple challenges after ingestion, including gastric acid, enzymatic degradation, antimicrobial peptides, bile acids, and secreted innate and adaptive immunoglobulins. A successful oral formulation of LBC typically requires enteric delivery to protect from the strong acidic environment in the stomach and target release into the small intestine or beyond, depending on the therapeutic target site. Thus LBC vaccines may be targeted to the ileum rich in Peyers patches, whereas some probiotics are targeted to the large intestine to modulate the intestinal microbiota. Enteric coatings are typically acid-insoluble films that stay intact during transit of solid oral doses through the stomach and subsequently dissolve and release contents as $\mathrm{pH}$ increases in the intestine. Tablets and granules are the most common solid oral enteric formulations but capsules can also be effectively enterically coated ${ }^{10}$. Enteric coatings can be used for three distinct purposes: firstly to protect gastric mucosa from irritant or toxic active pharmaceutical ingredient (API), secondly to deliver an API to a lower GI site, and thirdly to protect acid-labile API from gastric acid (e.g. omeprazole). Protection of gastric mucosa and intestinal delivery are both achieved by the enteric film layer remaining intact in acid preventing dose disintegration, whereas API protection is achieved by the enteric polymer film blocking ingress of acid into the solid formulation. Although most enteric polymers are acid insoluble, they do typically swell in acid with the degree of swelling and permeability of enteric polymer films varying dependent on polymer composition ${ }^{11,12}$. LBC formulations must achieve 
delivery to an intestinal site but protection from acid toxicity is also vital given the high sensitivity of dried bacteria to acid ${ }^{13,14}$. Research in enteric delivery has developed a spectrum of approved enteric polymers coupled to a broad range of coating methodologies. Further improvement of pharmaceutical polymer properties can be achieved by blending polymers to combine distinct desired properties and provide endlessly tunable coating performance ${ }^{12}$. For example, improved protection of API from acid was achieved by blending enteric polymers with insoluble polymers ${ }^{11,15,16}$.

LBC have been formulated using enteric coated tablets ${ }^{17}$, capsules ${ }^{18}$ and granules ${ }^{19}$. Protection from acid using co-administration with buffer solutions has also been used ${ }^{18}$, and microencapsulation has been explored for acid protection and controlled delivery ${ }^{20,21}$.In all cases drying is required to preserve cell viability during long term storage. However, the dehydration process can damage cells through osmotic and oxidative stress and also denaturation of biomolecules ${ }^{22}$. This can be prevented by sugar glasses formation, an effective and well understood approach to stabilization of biomacromolecules during drying ${ }^{23}$. Although much work has focused on freeze-drying, many bacteria and related complex biological payloads are more robust when freezing is avoided ${ }^{24}$. A continuous, ambient temperature drying process would also be more cost effective than freeze drying, where major costs are incurred by the slow batch turnaround and high cost of large scale freeze drying equipment. Other drying methods, including spray, fluidized bed, foam, vacuum and air convective drying have been explored for the industrial mass-production of dried microorganisms ${ }^{25}$. Perhaps the simplest ambient temperature drying method is to spread material in a thin film to provide a large surface area for evaporation. Ambient temperature drying on a flexible belt is used for continuous, scaleable drying of sensitive food products ${ }^{26,27}$. Ambient temperature drying onto polymer films has historically been used for preservation and storage of microbial reference samples ${ }^{28}$, but sophisticated film drying methods has recently been adopted for advanced biotechnology applications ranging from biocatalysis and biosensing to food technology. Flickinger and coworkers developed a sophisticated and robust method for painting and printing live bacteria, using polymer latex plus nontoxic adhesive films to permanently entrap cells, preserving cell viability and metabolic activity on surfaces at ambient temperatures ${ }^{29}$. Others have incorporated live lactic acid bacteria into an edible, flexible casein film, with high cell survival after drying and storage, as an antimicrobial meat packaging material ${ }^{30}$.

Here, we propose a novel approach to oral formulation of LBC which exploits the benefits of ambient film drying technology and inspired by a novel yet simple and powerful web formulation technology recently developed for oral delivery of small molecule APIs ${ }^{31,32}$. In the Sticky Web approach, a carefully metered dose of API in dry powder form adheres to an adhesive patch printed on a polymer film web. We propose that a cast film of enteric polymer can be used as a web for drying LBC allowing continuous and scaleable ambient temperature lyophilization and combination with a protective enteric film in a single unit operation (Figure 1a). The web comprising dried cells on enteric polymer film can then be directly laminated using edible adhesives to produce an oral solid dosage form (Fig 1b). The resulting polymer film laminate (PFL) formulation can be made using a variety of lamination methods, polymers and film thicknesses to provide fully customized LBC delivery. Here, we investigate if bacteria can 
be directly dried onto enteric polymer films, if this material is sufficient for protecting dried bacteria from gastric acid, and if a prototype oral PFL formulation can be used to deliver live vaccine and probiotic bacteria in simulated gastrointestinal fluids.

\section{Materials and Methods}

Materials. Eudragit L100 55 (Eudragit L, methacrylic acid-ethyl acrylate copolymer 1:1), was a kind gift from Evonik, Germany. Triethyl citrate, LB broth and LB agar were from Sigma Aldrich (Gillingham, UK). Dow Methocel E15 LV Hydroxypropyl methylcellulose (HPMC) (28-30\% Methoxyl, 7-12\% Hydroxypropyl content, 12-18mPAs at 2\% in water) was kindly supplied by Colorcon (UK). Bifidobacterium breve NCIMB 8807 was obtained from the U.K. National Collection of Industrial and Marine Bacteria (NCIMB). Ethyl cellulose (ethoxyl content $48 \%, 8$ to $11 \mathrm{cPs}$ at 5\% w/v in 80:20 toluene/ethanol) was from Acros Organics, Belgium. Wilkins-Chalgreen (WC) anaerobe agar was from Oxoid (Basingstoke, UK). Water Blue dye was purchased from Fluka, UK.

Preparation of polymer films. Polymer films were cast from solution by solvent evaporation as follows. Eudragit L100 55(12.5\% w/v), Ethylcellulose (EC) $(5 \% \mathrm{w} / \mathrm{v})$ or a blend of Eudragit:EC (with Eudragit to ethylcellulose ratio of 25:75, 50:50 or 75:25) were fully dissolved with stirring in ethanol and triethyl citrate plasticizer added to $25 \% \mathrm{w} / \mathrm{w}$ based on polymer mass. HPMC $(2 \% \mathrm{w} / \mathrm{v})$ was dispersed in deionized water heated to $90^{\circ} \mathrm{C}$ and then cooled with stirring to ensure complete dissolution following manufacturer recommended protocol. Polymer solutions were cast by solvent evaporation in $90 \mathrm{~mm}$ diameter Petri dishes with the volumes adjusted (7.5-50mL) to achieve the desired dry film thickness, measured using a micrometer at 5 points on each square of film used to dry LBC, with cast film thickness ranging from $60 \mu \mathrm{m}$ to $200 \mu \mathrm{m}$. Thicker films (up to $1 \mathrm{~mm}$ ) used to make spacers between laminated dried cell spots (Fig 1b) were cast from higher volumes. Films were dried at room temperature for 3 days or $40{ }^{\circ} \mathrm{C}$ for 2 days. Prior to making bacterial formulations, films were sterilized by UV irradiation for 15 minutes and thereafter handled aseptically. With enteric polymers complete solvent removal was important to prevent toxicity of the ethanol to dried LBC, and thermogravimetric analysis was performed on cast film samples to confirm absence of solvent.

Acid permeability of enteric polymer films. Two assays were used to compare the acid permeability of films cast from Eudragit alone or Eudragit:EC (50:50) blend. Swelling of films in acid was monitored to determine if acid could penetrate into polymer films. Polymer films pieces $(1.5 \times 1.5 \mathrm{~cm})$ were immersed in $30 \mathrm{~mL} \mathrm{SGF}$ solution $(0.1 \mathrm{M} \mathrm{HCl})$ at $37^{\circ} \mathrm{C}$ with stirring. To measure film dissolution samples were placed in a SIF solution of phosphate buffer $(\mathrm{pH} 7.0)$ at $37^{\circ} \mathrm{C}$ with stirring. In both cases, films were weighed before immersion and at the indicated timepoints after removing excess fluid on filter paper. Water gain was calculated as ((wet mass dry mass)/ dry mass) x 100 and expressed as swelling \% w/w. A Franz diffusion cell was also used to determine if acid could diffuse through cast enteric polymer films. Films cast from Eudragit L100 55 or Eudragit:EC (50:50) blend were compared with a control dialysis membrane (12-14000Da MWCO, Medicell International, UK). To prevent film dissolution which will occur with Eudragit at $\mathrm{pH}$ greater than 5.5, films were equilibrated in deionized water with the $\mathrm{pH}$ adjusted to 4.2 prior to mounting in the diffusion cell, and the acceptor chamber was 
filled with deionized water at $\mathrm{pH} 4.2$. The top donor chamber was loaded with $0.1 \mathrm{M} \mathrm{HCl}(\mathrm{pH}$ 2.0) and the lower acceptor chamber was continually stirred and $\mathrm{pH}$ monitored at indicated timepoints up to $6 \mathrm{~h}$.

Ambient temperature drying of therapeutic bacteria onto polymer films. Two model therapeutic bacterial strains were selected: the anaerobic Gram positive model probiotic Bifidobacterium breve (strain NCIMB 8807) and the aerobic Gram negative model mouse live attenuated vaccine Salmonella Typhimurium strain SL3261. Single colonies of B. breve from Wilkins-Chalgreen anaerobe agar were inoculated into $10 \mathrm{~mL}$ trypticase-phytone-yeast (TPY) broth, adjusted to optimal starting density and incubated anaerobically at $37^{\circ} \mathrm{C}$ for $21-22$ hours to obtain cultures with an $\mathrm{OD}_{600}$ of 2.0 corresponding to late log phase/initial stationary phase of growth. Single colonies of $S$. Typhimurium SL3261 from LB agar were inoculated into $10 \mathrm{~mL}$ LB broth, adjusted to optimal starting density and incubated at $37^{\circ} \mathrm{C}$ for $18-20$ hours to obtain cultures with an $\mathrm{OD}_{600}$ of 2.0 corresponding to late log phase/early stationary growth phase. 1 $\mathrm{mL}$ aliquots of cells were harvested in microcentrifuge tubes by centrifugation (10000 rpm, 10 min), supernatant removed and cell pellets resuspended in $100 \mu \mathrm{L}$ sterile lyoprotectant mix of deionized water with $40 \% \mathrm{w} / \mathrm{v}$ trehalose. Measured volumes of the resultant cell slurry were either placed dropwise in spots on cast polymer films, or spread over $1.5 \mathrm{~cm}^{2}$ films. LBC on films were dried in a desiccator for at least 18 hours; this time was chosen because in kinetic analysis of the drying process after $16 \mathrm{~h}$ no further water loss was measurable. Residual water content of samples of cells dried onto polymer films was determined using thermogravimetric analysis (TGA), using $5^{\circ} \mathrm{C} /$ minute ramp rate from $25^{\circ} \mathrm{C}$ to $200^{\circ} \mathrm{C}$ in a TA instruments Q500 Thermogravimetric Analyzer. Initial experiments were conducted at room temperature, however it was noted that laboratory temperature varied sufficiently to significantly alter cell recovery post drying and dried cell phenotype; subsequently all drying was completed in environmental chambers with controlled drying temperature. Drying temperature for experiments presented in Figures 2, 5 and 7 was $20^{\circ} \mathrm{C}$ and for experiments presented in Figure 4 drying temperature was $26^{\circ} \mathrm{C}$. Temperature and relative humidity during drying were monitored using a USB datalogger (Omega, UK), and stayed within $\pm 1^{\circ} \mathrm{C}$ from indicated drying temperature with relative humidity staying between $4-6 \%$.

Viable cell counting. Live cell recovery was evaluated using serial dilution of samples and agar plate colony counting at all steps: before and after drying onto polymer films, and during acid resistance and dissolution tests. Serial 3-fold dilutions were made in TPY or LB broth in sterile 96 -well plates with a multichannel pipettor. In detail, $10 \mu \mathrm{L}$ spots dried onto polymer film were rehydrated in $10 \mathrm{~mL}$ of rehydration medium, of which $50 \mu \mathrm{L}$ samples were transferred into $100 \mu \mathrm{L}$ of broth, to complete 16 serial 3-fold dilutions and $5 \mu \mathrm{L}$ samples of each dilution were then spotted onto square plates of Wilkins-Chalgreen anaerobe or LB agar to give dilution factors of $10^{5}$ to $10^{10}$. To determine lowest detection limit of $10^{3} \mathrm{CFU} / \mathrm{mL} 10 \mu \mathrm{L}$ samples was also plated directly from rehydration medium. Samples were dried for 10-15 minutes prior to incubation. $B$. breve plates were incubated anaerobically at $37^{\circ} \mathrm{C}$ for at least 48 hours and $S$. Typhimurium plates were incubated aerobically at $37^{\circ} \mathrm{C}$ for at least 24 hours. Colonies were counted and final viability expressed as colony forming unit per $\mathrm{mL}(\mathrm{CFU} / \mathrm{mL})$ calculated relative to the initial volume cell slurry. To follow viable cell recovery after drying and exposure 
to simulated GI conditions viable cell counts were expressed relative to the initial volume of cell slurry before drying.

Acid protection after direct drying onto enteric polymer films. Cells were dried onto the enteric polymer Eudragit or a blend of Eudragit and ethylcellulose as above, and resistance to acid tested by pipetting $40 \mu \mathrm{L}$ of $\operatorname{SGF}(0.1 \mathrm{M} \mathrm{HCl})$ on the film surface on the opposite side to the dried cells; as a control the same volume of SGF was pipetted directly onto the cell spot on the film (see diagram in Figure 4). After 2 hours of exposure to acid the viability was determined by complete dissolution into buffered peptone water and compared to the viability of replicate samples directly released into buffered peptone water.

Preparation of polymer film laminate oral formulations. To produce encapsulated polymer film laminate (PFL) formulations, cells were dried onto $1.5 \mathrm{~cm}^{2}$ Eudragit or Blend polymer film squares and two complete squares were laminated either side of a single layer of thick film or multiple layers of film containing a central hole of an equal size to the dried cell spot (Figure 1b), thereby encapsulating the dried cells. Prototype formulations were produced using either, double sided adhesive tape or rapid setting, non-toxic cyanoacrylate adhesive to seal the multiple polymer film layers around the dried cells or dye. To produce thick film (TF) formulations

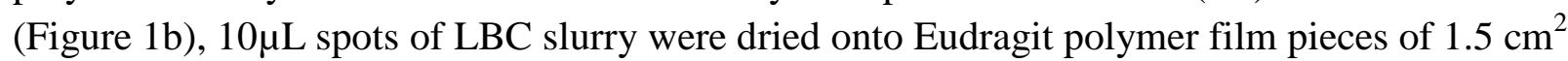
as described above. A square of thicker cast polymer film $(1 \mathrm{~mm})$ was prepared with a central hole punched of an equal size to the dried cell spot (4mm diameter), and cyanoacrylate adhesive used to seal cell-bearing polymer film squares face to face on either side of the thick film, enclosing the dried cells. Multi-Laminate film (MLF) formulations (Figure 1b) were produced from two film squares with dried cell spots separated face-to-face around 10 layers of thin (100 $\mu \mathrm{m})$ polymer film with punched holes; the 10 thin layers with punched holes were laminated first with cyanoacrylate adhesive, and after curing for $1 \mathrm{~h}$ the outer two film squares were sealed with cyanoacrylate adhesive. In all cases, during sealing laminates were compressed with moderate pressure for $1 \mathrm{~h}$ to allow the adhesive to cure fully prior to in vitro dissolution tests. In some tests, Water Blue dye was incorporated instead of dried cells to study small molecule release from laminates; $1.5 \mathrm{mg}$ of dye powder was encapsulated within the laminate formulation.

\section{Protection and live cell release from polymer film laminate formulation in simulated} gastrointestinal conditions. Prototype PFL formulations were immersed in simulated gastric fluid (SGF) (pH 2.0, $20 \mathrm{~mL}$ of $0.1 \mathrm{M} \mathrm{HCl}$ ) at $37^{\circ} \mathrm{C}$ for 2 hours with orbital shaking at $100 \mathrm{rpm}$. Samples were taken at 0,1 and 2 hours and live cell release counted, although PFL formulations remained intact in SGF with no dissolution or cell release detected by visual inspection. After 2 hours in SGF, formulations were transferred into $10 \mathrm{~mL}$ simulated intestinal fluid (SIF) (0.68\% w/v monobasic potassium phosphate and $1.5 \% \mathrm{w} / \mathrm{v}$ peptone at $\mathrm{pH} 7.0$ ) and incubated at $37^{\circ} \mathrm{C}$ with orbital shaking at $100 \mathrm{rpm}$. Samples were taken and live cell release determined at $0,1,2$ and 3 hours after transfer from SGF. For each experiment identical samples of LBC dried onto films but not laminated were incubated for $20 \mathrm{~min}$ in SIF and live cell recovery counted to determine the post-drying viable cell number prior to making and testing PFL formulations.

Kinetics of dissolution and dye release from polymer film laminates. Prototype PFL formulations containing Water Blue dye were immersed in SGF ( $\mathrm{pH}$ 2.0, $20 \mathrm{~mL}$ ) for 2 hours at 
$37^{\circ} \mathrm{C}$, with shaking. Samples were taken from this solution at 0,1 and 2 hours and dye concentration measured spectrophotometrically at $\lambda=580 \mathrm{~nm}$. After 2 hours, formulations were

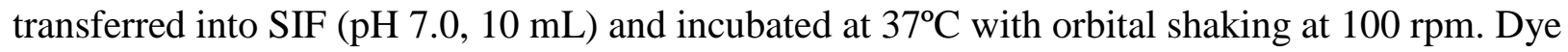
concentration was measured at the indicated times and percentage of dye released calculated.

\section{Statistical analysis}

Data and results are reported as mean with error bars indicating standard deviation. Statistical evaluation of comparing the significance of the difference in viability between the means of two groups was performed using a two-tailed unpaired Student's $t$-test; a value of $p<0.05$ was accepted as significant.

\section{Results and Discussion}

Drying bacteria onto enteric polymer films. Although we envisage that cells can be continuously dried onto a polymer web (Figure. 1a), our focus in this study was to determine the feasibility of successfully drying bacteria onto a cast enteric polymer film, and protecting from acid. Initial experiments therefore investigated the conditions needed for effective ambient temperature drying of vaccine and probiotic LBC onto films of pharmaceutical polymers acceptable for oral delivery. Cells of a model probiotic strain of $B$. breve were mixed with a protectant mix containing the lyoprotectant trehalose and dried at ambient temperature onto films cast from pharmaceutical polymers. A drying time of 16 - 20 hours was established by completing detailed analysis of the kinetics of drying by monitoring sample mass at hourly intervals. These studies showed that $>95 \%$ water loss was achieved by $16 \mathrm{~h}$, with no significant further water loss at $20 \mathrm{~h}$ and beyond. After drying, the residual water content of $3.32 \pm 0.53 \%$, $(n=3)$ of the dried cells was determined by thermogravimetric analysis. Two methods were directly compared to ensure controlled and even distribution of cells onto cast films prior to drying: either a measured volume of cell slurry was spread over a marked area of polymer film, or drops of the same cell slurry in identical excipient were dried without spreading to produce a 'cell spot' of known cell dose. Although the surface area after spreading was 3 times higher than cell spots ( $2.25 \mathrm{vs} 0.8 \mathrm{~cm}^{2}$ ) which would likely result in a faster drying rate, both samples of dried cells were tested for viable cell recovery at the same timepoint and no difference in viability on HPMC films after drying was observed between these methods (Figure 2a). Subsequent experiments were therefore performed using dried cell spots of fixed volume and thus known input LBC number. Acceptable viability post-drying was achieved onto enteric polymer films cast from Eudragit alone or a blend of Eudragit:EC (50:50 w/w), as well as HPMC films (Figure 2b). The highest live cell recovery was achieved onto HPMC films with a cell loss of $0.5 \mathrm{log}$, with drying onto enteric polymer films giving slightly greater loss of viability of up to $1 \log$ (Figure 2b).

Previous work has already established that drying LBC can reduce cell viability to an extent that depends on the drying process, cell strain and growth stage, and lyoprotectant excipients ${ }^{25,33}$. In pilot experiments with $B$. breve, the loss in cell viability observed after drying onto cast polymer films ranged from $0.5 \log \operatorname{loss}$ (e.g. Fig 2) to >3 log loss. The excipient in which cells 
were resuspended prior to drying and the drying temperature were the variables which had the greatest influence over post-drying viability. The excipient trehalose was chosen for experiments performed here as when compared to other excipient mixes (e.g. buffer or medium alone) it provided the most consistent live cell recovery in a range of different drying conditions.

Increasing the drying temperature from $20^{\circ} \mathrm{C}$ to $35^{\circ} \mathrm{C}$ resulted in lower post-drying viability. For example, when dried at $20^{\circ} \mathrm{C}$ between 1.2-1.5 log loss of viable cell count was observed; in contrast, at $35^{\circ} \mathrm{C}$ from 2.6 to $3.4 \log$ loss was observed. The surface onto which LBC were dried also had a moderate but significant influence over loss during drying, with drying onto Eudragit and Eudragit:EC blend films resulting in greater loss of viability than drying onto HPMC (Figure 2b). Similar viable cell recovery was observed after LBC drying onto films cast from other pharmaceutical polymers including alginate and Aqoat ${ }^{\mathrm{TM}}$ HPMC-AS (data not shown). Further investigations are required to understand how the polymer film surface influences LBC loss during drying.

One main aim of drying therapeutic LBC is to improve product stability, since in general dried microorganisms can retain viability for longer than liquid cultures. Although many factors affect the stability of dried LBC and the focus of this study was not to achieve thermostability, it is important that dried cells had residual moisture below $10 \%,{ }^{34,35}$ as observed by TGA. However, the optimum residual moisture content for stability varies with the composition of the fluid in which organisms are dried, with the storage atmosphere, the species and strain, and the physiological state of the organisms,${ }^{36}$ and so optimum water content for longest product stability will need to be individually determined for each LBC formulated.

Acid permeability of enteric polymer films. Published studies ${ }^{11,12}$ have established that a hydrophobic polymer such as EC can be blended with enteric polymers such as Eudragit to increase the protection of an API from acid. Protecting dried bacteria from gastric acid is especially important here because of their increased acid sensitivity compared to cells in culture ${ }^{13}$, combined with the direct contact between dried cells and the enteric film. We thus compared films cast from both Eudragit and a Eudragit:EC (50:50) blend for acid permeability. The methacrylic acid : ethyl acrylate copolymer Eudragit L was used, which dissolves above pH 5.5. When enteric polymer films were immersed in SGF, they remained intact but swelling and mass gain was observed indicating a degree of acid permeability. As expected ${ }^{11,15,16}$ the degree of swelling in SGF was lower and slower with Eudragit:EC than Eudragit alone (Figure 3a).

Although swelling was observed with both Eudragit and Eudragit:EC blend films in SGF indicating penetration of acid into the polymer, this assay did not indicate whether acid can penetrate fully through the films. The penetration of acid through films was therefore tested using a Franz diffusion cell. To prevent rapid dissolution of the film, the acceptor chamber was filled with water acidified to $\mathrm{pH}$ 4.2. The donor chamber was filled with SGF (pH 2.0), and as expected a control cellulose dialysis membrane allowed acid to rapidly permeate, with the acceptor chamber $\mathrm{pH}$ equilibrating to $\mathrm{pH} 2.5$ by 4 hours (Figure $3 \mathrm{~b}$ ). In contrast, the acceptor $\mathrm{pH}$ remained at pH4.2 with either Eudragit or Eudragit:EC films (Figure 3b), demonstrating the acid impermeability of these films. No acid permeation was observed through Eudragit and Eudragit:EC blend films ranging in thickness from $75-350 \mu \mathrm{m}$ (data not shown). Having 
measured acid permeability, films were then tested at $\mathrm{pH} 7.0$ to check dissolution and release in intestinal conditions. Eudragit films fully dissolved within 30 min immersion in SIF pH 7.2 (Figure 3c),but Eudragit:EC blend films gained weight and swelled, reaching 5x starting weight by 6 hours (Figure 3c), gaining characteristics of a hydrogel. This indicated that the Eudragit had leached out of the film leaving a porous network of insoluble EC, and raised the possibility that blended films with increased acid impermeability may not be able to release LBC.

Protecting dried LBC from acid with enteric polymer films. Having established that Eudragit:EC blend films were less acid permeable than Eudragit alone, but that both films were equally able to block acid diffusion, the ability of the two enteric films to protect dried LBC from direct acid exposure was compared. In these experiments, cells were dried onto enteric films at an increased temperature of $26^{\circ} \mathrm{C}$, resulting in greater cell loss on drying than that observed in previous experiments where drying was conducted at $20^{\circ} \mathrm{C}$ (compare Figures 2 vs 4 ). To avoid this increased loss of viability on drying, in subsequent experiments (see Figures 5 and 7 below) a drying temperature of $20^{\circ} \mathrm{C}$ was used.

When dried cells were exposed directly to SGF, viability rapidly dropped below the limit of detection of $<10^{3} \mathrm{CFU} / \mathrm{mL}$ representing a $>10^{5}$-fold loss. In contrast, when acid was placed on the opposite side of films for 2 hours, followed by determination of remaining viable cell counts, significant numbers of viable cells were recovered (Figure 4), confirming that enteric polymer films are sufficient to provide a degree of protection from acid. As expected from the Franz diffusion cell study, both enteric films protected dried cells when SGF was placed onto the film surface opposite the dried cells for 2 hours (Figure 4). However, the cell recovery seen after 2 hours acid exposure was greater with the Eudragit:EC blend than Eudragit alone, indicating that the blended polymer film provided improved protection from acid in agreement with the swelling results (Figure 3a) and prior work ${ }^{11,15,16}$. Indeed, with the Eudragit:EC blend less than $0.5 \log$ reduction in viable cell recovery was observed after 2 hours exposure of the film to SGF. In contrast, a nearly $2 \log$ reduction in viable cell recovery was seen with pure Eudragit films, suggesting that the observed swelling in acid (Figure 3a) may have also allowed sufficient acid to permeate through films to adversely affect the viability of cells dried onto Eudragit films. It is possible that the increased viable cell recovery with Eudragit:EC blend over Eudragit alone films could be attributable to increased release of viable cells, rather than simply increased protection from acid. However, both films released similar viable cell numbers when directly exposed to SIF, with the small apparent increase in cell release from Eudragit:EC blend films not being found to be statistically significant (figure $4 ; \mathrm{p}>0.05$ ).

We conclude that cells dried directly onto enteric polymer films can be protected from acid. Significant cell recovery after two hours acid exposure was achieved, with an Eudragit:EC blend offering better acid protection than Eudragit alone.

Prototype Polymer Film Laminate oral formulations. Live bacterial cells were dried onto enteric polymer films and prototype solid oral formulations illustrating the Polymer Film Laminate concept (Figure 1) were made and tested. To evaluate the suitability of PFL made from enteric polymer films for protecting live dried LBC from gastric acid and subsequently releasing viable cells into the intestine, prototypes were tested in simulated gastrointestinal conditions ( 2 
hours in SGF pH 2.0 and 3 hours in SIF pH 7.0) and cell viability sampled at regular timepoints. Prototype PFL containing a single $10 \mu \mathrm{L}$ spot of dried cells with a viable cell density equivalent to $10^{9} \mathrm{CFU} / \mathrm{mL}$ (i.e. approximately $10^{7} \mathrm{CFU}$ B. breve per dose) were made by laminating either Eudragit or Eudragit:EC blend films together using layers of adhesive tape with a central hole cut matching the dried cell spot (Figure 1b). After 2 hours of exposure in SGF pH 2.0, both Eudragit or Eudragit:EC blend formulations were intact and no cells released. Importantly, 1 hour after transfer into SIF pH 7.0, the Eudragit PFL formulations had fully dissolved and cell recovery equivalent to the starting cell density of $10^{9} \mathrm{CFU} / \mathrm{mL}$ was observed, indicating no loss in cell viability after $2 \mathrm{~h}$ in SGF at pH 2.0 (Figure 5). In contrast, after 3 hours in SIF pH 7.0 the Eudragit:EC blend PFL became highly swollen but intact with no disruption of the polymer matrix, and no viable cells were recovered in SIF pH 7.0 (Figure 5). This was surprising considering the improved protection from acid seen with film alone (Figure 4). Indeed, when swollen Eudragit:EC blend PFL samples were mechanically disrupted significant numbers ( $>2 \times 10^{7} \mathrm{CFU} / \mathrm{mL}$ ) of viable cells were recovered (data not shown) suggesting that the absence of viable cell recovery was not due to loss of cell viability but instead represented a failure to release $\mathrm{LBC}$.

To determine if the Eudragit:EC films were capable of releasing low molecular weight molecules into SIF, dye release studies were completed with PFL made from Eudragit or Eudragit:EC blend loaded with Water Blue dye instead of dried LBC, and exposed to SGF followed by SIF. In contrast to the lack of release of LBC from the Eudragit:EC PFL prototype, complete release $(>90 \%)$ of Water Blue dye was seen from both enteric polymer formulations within 1 hour of transfer from SGF into SIF (Figure 6) confirming that although the Eudragit:EC PFL does not fully dissolve at pH 7.0, it can still release low molecular weight contents. In previous work where Eudragit:EC film coatings were applied to tablets, rapid release was achieved, possibly due to disintegration of the tablet following swelling at elevated $\mathrm{pH}^{37}$.

We conclude that although blending enteric polymers with ethylcellulose can increase protection from acid and is suitable for film coating tablets and low molecular weight APIs, the blended film is unsuitable for LBC delivery in PFL. This observed poor release from PFL could be attributed to a number of reasons, including the large size of bacterial cells or interactions between bacterial cells and EC. Although electrostatic interactions between neutral (EC) and negatively charged (Eudragit) polymers with negatively charged bacterial cells is unlikely, but undissolved EC could bind cells through hydrophobic interactions. Further studies of the porosity of Eudragit:EC films are required to fully understand the range of APIs that could be successfully released from formulations formed from this polymer blend.

Surprisingly, although in acid protection experiments significant cell loss - of up to 100-fold compared to controls samples not exposed to acid - was observed with Eudragit films (Figure 4), complete recovery of identical viable cell counts to control samples was seen from Eudragit PFL (Figure 5) after 2 hours exposure to SGF in both experiments. There are two explanations of the improved protection from acid seen with prototype PFL compared to the previous experiments where acid was simply pipetted onto the opposite side of Eudragit films to dried cells. Firstly, it is possible that dried cells within PFL are better sealed from acid than the film pieces exposed to 
acid without lamination. Secondly, in acid protection studies (Figure 4) cells were dried at $26^{\circ} \mathrm{C}$ whereas in contrast prototype PFL formulations were made from cells dried at a lower temperature of $20^{\circ} \mathrm{C}$ (Figure 5). This temperature was chosen to reduce cell loss during drying, as when drying temperatures were directly compared it was discovered that drying at the an elevated temperature of $35^{\circ} \mathrm{C}$ gave 2.6 to $3.4 \log$ loss of viability, in contrast to drying at $20^{\circ} \mathrm{C}$ where loss was 1.2 to $1.5 \mathrm{log}$. Further preliminary studies suggested that increased drying temperatures increase the sensitivity of dried cells to acid as well as reducing viability after drying (Figures 4 vs 5 and unpublished observations).

In conclusion, the Eudragit PFL is capable of efficiently protecting dried live probiotic bacteria from $2 \mathrm{~h}$ immersion in SGF. Although the drying process always gave a loss close to 1-log reduction in viable cell number, the overall delivery efficiency considering all process steps is adequate and compares well with other formulations of probiotic cells ${ }^{20,38}$.

Controlled probiotic and vaccine release from enteric PFL formulations. Building on the observation that live cells are protected from acid and rapidly released from Eudragit PFL formulations, further PFL were made with varying bacterial payload, film thickness, type of adhesive and method of lamination. Firstly, the effect of PFL construction on protection from SGF and release in SIF was investigated. PFL containing B. breve dried onto Eudragit films were laminated using adhesive tape or non-toxic cyanoacrylate adhesive. The use of multiple thin spacers laminated between cell-loaded films was compared to a single thick spacer layer. In all cases, endpoint cell recovery was excellent, with cell recovery 3 hours post transfer into SIF identical to that seen when replicated samples of cells dried onto films were directly incubated for 20 minutes in SIF without lamination, indicating no loss of viability after 2 hours immersion in SGF (Figure 7a). However, different release kinetics were observed depending on the lamination method and adhesive used. Thus although complete cell release was seen after only 60 minutes in SIF with PFL produced from multiple layers of thin film laminated with adhesive tape, or when thick Eudragit films were laminated using edible adhesive, in contrast complete cell recovery was delayed until 3 hours after transfer into SIF when multiple layers of thin films were laminated with edible adhesive (Figure 7a). This delay in release is most likely to be caused by the increased amount of adhesive present with the MLF formulations that appeared to slow down the film disintegration in SIF. This excess of adhesive with prototype MLF formulations was caused by the manual lamination method and could be overcome by accurately metering the quantity of edible adhesive used to assemble PFL.

Although experiments with the model probiotic $B$. breve demonstrated the concept of direct enteric formulation of dried cells, bacteria vary significantly in their response to drying and resistance to gastrointestinal microbicides. Therefore similar PFL formulations were produced using the model live bacterial vaccine Salmonella enterica subspecies Typhimurium strain SL3261. The viability of $S$. Typhimurium after drying onto Eudragit films was excellent when measured after direct release in SIF, with less than $0.5 \log$ loss post-drying (Figure $7 \mathrm{~b}$ ). In contrast, when directly exposed to SGF pH 2.0 no viable cells were recovered, as expected given the known sensitivity of this strain to $\mathrm{pH}<3$ (data not shown and ${ }^{13}$ ). Importantly, when PFL were made from $S$. Typhimurium dried onto Eudragit films following 2 hours immersion in SGF, 
followed by transfer to SIF, complete viable cell release was achieved (Figure 7b). When Eudragit film thickness was varied, the kinetics of vaccine cell release could be modified, with $100 \mu \mathrm{m}$ films releasing total LBC load within $60 \mathrm{~min}$ of transfer into SIF in contrast to $165 \mu \mathrm{m}$ films which delayed release until 2-3 hours after transfer (Figure 7b).

By varying film thickness and PFL lamination method, controlled enteric release of viable LBC from a solid oral formulation is feasible. The recovered relative cell density of $10^{10}$ $\mathrm{CFU} / \mathrm{mL}$ (expressed relative to the initial cell volume) from prototype PFL produced containing a single spot dried from $10 \mu \mathrm{L}$ cells indicates a live cell dose of $10^{8}$ viable cells per formulation, and confirms the feasibility of producing PFL with standard doses of LBC, where typical oral doses of both live bacterial vaccines and probiotics range from $10^{8}$ to $10^{10}$ viable bacteria ${ }^{18,39,40}$. Increasing LBC dose beyond $10^{8}$ can be achieved simply by increasing the number of dried cell spots in the PFL, or by increasing the cell density in the slurry, the volume of slurry and the area of the dried cell spot. The post-drying viability, cell dose delivered, and product stability of formulated dried LBC is already known to depend upon a wide range of variables, including cell species and strain, culture conditions, drying conditions and excipients used ${ }^{33}$, for this reason it will be essential for systematic multivariate DoE optimization to be used to develop specific formulations using this new process.

PFL represents an alternative to other oral formulations explored for LBC delivery including tablets, capsules, and microcapsules ${ }^{21}$. Potential benefits include low-cost scaleable continuous drying, for example utilizing Refractance Window drying ${ }^{26,27}$. The PFL concept has similarities to orodispersable films used for delivery of small molecule APIs such as rasagiline mesylate or tadalafil, used as a substrate for metered drug printing ${ }^{41}$.

Although these results indicated that live cell delivery is feasible using PFL, the live cell dose achieved, cell phenotype after release, and exact location of live cell release cannot be accurately predicted from the simple in vitro dissolution conditions used here. Further in vitro survival and release studies are planned using more complex simulated gastrointestinal fluids, for example including physiological concentrations of intestinal microbicides such as bile acids ${ }^{14,42}$. Ultimately however, the performance of PFL for therapeutic LBC delivery must be tested by determining live cell release in animal models that mimic human GI transit (e.g. using large monogastric mammal such as pigs), and therapeutic benefits such as vaccine immunogenicity or modulation of GI microbiota using probiotics can only be determined in human clinical studies.

Conclusions These studies demonstrate the feasibility of a new oral formulation concept for simple, effective, controlled enteric delivery and protection from acid of sensitive complex biologic payload such as live bacteria for vaccine and probiotic applications. Although maximum protection from acid of bacteria dried onto enteric polymer films was achieved when Eudragit was blended with ethylcellulose to reduce film permeability in acid, to achieve release of cells Eudragit alone was required which fully dissolved at intestinal $\mathrm{pH}$. The release kinetics and thereby intestinal release site could be modified by altering the thickness of polymer films used to produce PFL, and by altering the lamination method and adhesive used. The therapeutic LBC dose, timing and location of release depend on the specific LBC application, with vaccines requiring release into the ileum and probiotics benefitting from colonic targeting. Our target 
critical product attributes were therefore to achieve complete protection from acid, and variable kinetics of release to allow controlled LBC targeting. This target was achieved, therapeutically relevant dose of $10^{8} \mathrm{CFU}$ of a model attenuated vaccine was released within 1 hour after transfer into SIF following 2 hours exposure to SGF. Further studies of PFL are warranted to determine stability, viable cell delivery in conditions that fully simulate gastrointestinal transit, and ultimately in preclinical models, to determine in vivo cell delivery performance for therapeutic live bacteria.

\section{ACKNOWLEDGMENTS}

We are grateful to the University of Reading and Reading School of Pharmacy for studentship funding to JB. We thank Clare Bryant for providing the model vaccine strain, and would like to acknowledge the Chemical Analysis Facility at the University of Reading for the use of equipment and expertise.

\section{REFERENCES}

1. Levine MM 2006. Enteric infections and the vaccines to counter them: future directions. Vaccine 24(18):3865-3873.

2. Medina E, Guzmán CA 2001. Use of live bacterial vaccine vectors for antigen delivery: potential and limitations. Vaccine 19(13-14):1573-1580.

3. Bron PA, van Baarlen P, Kleerebezem M 2012. Emerging molecular insights into the interaction between probiotics and the host intestinal mucosa. Nature reviews Microbiology 10(1):66-78.

4. Guarner F, Malagelada J-R 2003. Gut flora in health and disease. The Lancet 361(9356):512-519.

5. Steidler L, Neirynck S, Huyghebaert N, Snoeck V, Vermeire A, Goddeeris B, Cox E, Remon JP, Remaut E 2003. Biological containment of genetically modified Lactococcus lactis for intestinal delivery of human interleukin 10. Nature biotechnology 21(7):785-789.

6. Duan F, Curtis KL, March JC 2008. Secretion of insulinotropic proteins by commensal bacteria: rewiring the gut to treat diabetes. Applied and environmental microbiology 74(23):7437-7438.

7. Kantele A, Arvilommi H, Kantele JM, Rintala L, Makela PH 1991. Comparison of the human immune response to live oral, killed oral or killed parenteral Salmonella typhi TY21A vaccines. Microbial pathogenesis 10(2):117-126.

8. Sander LE, Davis MJ, Boekschoten MV, Amsen D, Dascher CC, Ryffel B, Swanson JA, Müller M, Blander JM 2011. Detection of prokaryotic mRNA signifies microbial viability and promotes immunity. Nature 474(7351):385-389.

9. Adams CA 2010. The probiotic paradox: live and dead cells are biological response modifiers. Nutrition research reviews 23(1):37-46.

10. Huyghebaert N, Vermeire A, Remon JP 2004. Alternative method for enteric coating of HPMC capsules resulting in ready-to-use enteric-coated capsules. European journal of pharmaceutical sciences : official journal of the European Federation for Pharmaceutical Sciences 21(5):617-623. 
11. Lecomte F, Siepmann J, Walther M, MacRae R, Bodmeier R 2003. Blends of enteric and GIT-insoluble polymers used for film coating: physicochemical characterization and drug release patterns. Journal of controlled release 89(3):457-471.

12. Siepmann F, Siepmann J, Walther M, MacRae RJ, Bodmeier R 2008. Polymer blends for controlled release coatings. Journal of Controlled Release 125(1):1-15.

13. Edwards AD, Slater NKH 2008. Formulation of a live bacterial vaccine for stable room temperature storage results in loss of acid, bile and bile salt resistance. Vaccine 26(45):56755678.

14. Edwards AD, Slater NKH 2009. Protection of live bacteria from bile acid toxicity using bile acid adsorbing resins. Vaccine 27(29):3897-3903.

15. Siepmann F, Siepmann J, Walther M, MacRae RJ, Bodmeier R 2005. Blends of aqueous polymer dispersions used for pellet coating: Importance of the particle size. Journal of Controlled Release 105(3):226-239.

16. Lecomte F, Siepmann J, Walther M, MacRae RJ, Bodmeier R 2004. Polymer blends used for the aqueous coating of solid dosage forms: importance of the type of plasticizer. Journal of Controlled Release 99(1):1-13.

17. Stadler M, Viernstein H 2003. Optimization of a formulation containing viable lactic acid bacteria. Int J Pharm 256(1-2):117-122.

18. Levine MM, Ferreccio C, Abrego P, Martin OS, Ortiz E, Cryz S 1999. Duration of efficacy of Ty21a, attenuated Salmonella typhi live oral vaccine. Vaccine 17 Suppl 2:S22-27. 19. Huyghebaert N, Vermeire A, Neirynck S, Steidler L, Remaut E, Remon JP 2005. Development of an enteric-coated formulation containing freeze-dried, viable recombinant Lactococcus lactis for the ileal mucosal delivery of human interleukin-10. European Journal of Pharmaceutics and Biopharmaceutics 60(3):349-359.

20. Cook MT, Tzortzis G, Charalampopoulos D, Khutoryanskiy VV 2011. Production and evaluation of dry alginate-chitosan microcapsules as an enteric delivery vehicle for probiotic bacteria. Biomacromolecules 12(7):2834-2840.

21. Cook MT, Tzortzis G, Charalampopoulos D, Khutoryanskiy VV 2012.

Microencapsulation of probiotics for gastrointestinal delivery. Journal of Controlled Release 162(1):56-67.

22. Crowe JH, Hoekstra FA, Crowe LM 1992. Anhydrobiosis. Annual Review of Physiology 54(1):579-599.

23. Ohtake S, Wang YJ 2011. Trehalose: current use and future applications. Journal of pharmaceutical sciences 100(6):2020-2053.

24. Santivarangkna C, Kulozik U, Foerst P 2007. Alternative drying processes for the industrial preservation of lactic acid starter cultures. Biotechnology progress 23(2):302-315. 25. Morgan C, Herman N, White P, Vesey G 2006. Preservation of micro-organisms by drying; a review. Journal of Microbiological Methods 66(2):183-193.

26. Nindo C, Tang J 2007. Refractance window dehydration technology: a novel contact drying method. Drying technology 25(1):37-48.

27. Nindo CI, Sun T, Wang S, Tang J, Powers J 2003. Evaluation of drying technologies for retention of physical quality and antioxidants in asparagus ( $<\mathrm{i}>$ Asparagus officinalis $</ \mathrm{i}>$, L.). LWT-Food Science and Technology 36(5):507-516.

28. Suslow TV, Schroth MN 1981. Bacterial culture preservation in frozen and dry-film methylcellulose. Applied and environmental microbiology 42(5):872-877.

29. Flickinger MC, Schottel JL, Bond DR, Aksan A, Scriven L 2007. Painting and printing living bacteria: engineering nanoporous biocatalytic coatings to preserve microbial viability and intensify reactivity. Biotechnology progress 23(1):2-17. 
30. Gialamas H, Zinoviadou KG, Biliaderis CG, Koutsoumanis KP 2010. Development of a novel bioactive packaging based on the incorporation of $<\mathrm{i}>$ Lactobacillus sakei $</ \mathrm{i}>$ into sodium-caseinate films for controlling $<\mathrm{i}>$ Listeria monocytogenes $</ \mathrm{i}>$ in foods. Food Research International 43(10):2402-2408.

31. Barlow S, Biddle H, HAINES R, Smith K. 2010. Process for Providing a Quantity of a Particulate Material, Product and Apparatus. ed.: GSK.

32. Biddle H 2009. Case study: printing powders with Sticky Web technology.

Pharmaceutical Technology Europe 21(11).

33. Fu N, Chen XD 2011. Towards a maximal cell survival in convective thermal drying processes. Food Research International 44(5):1127-1149.

34. García A 2011. Anhydrobiosis in bacteria: From physiology to applications. J Biosci 36(5):939-950.

35. Potts M, Slaughter SM, Hunneke F-U, Garst JF, Helm RF 2005. Desiccation Tolerance of Prokaryotes: Application of Principles to Human Cells. Integrative and Comparative Biology 45(5):800-809.

36. Fry RM, Greaves RI 1951. The survival of bacteria during and after drying. The Journal of hygiene 49(2-3):220-246.

37. Rujivipat S, Bodmeier R 2010. Improved drug delivery to the lower intestinal tract with tablets compression-coated with enteric/nonenteric polymer powder blends. European Journal of Pharmaceutics and Biopharmaceutics 76(3):486-492.

38. Ohtake S, Martin RA, Saxena A, Lechuga-Ballesteros D, Santiago AE, Barry EM, Truong-Le V 2011. Formulation and stabilization of Francisella tularensis live vaccine strain. J Pharm Sci 100(8):3076-3087.

39. Sazawal S, Hiremath G, Dhingra U, Malik P, Deb S, Black RE 2006. Efficacy of probiotics in prevention of acute diarrhoea: a meta-analysis of masked, randomised, placebocontrolled trials. The Lancet infectious diseases 6(6):374-382.

40. Dietrich G, Griot-Wenk M, Metcalfe IC, Lang AB, Viret J-F 2003. Experience with registered mucosal vaccines. Vaccine 21(7-8):678-683.

41. Janßen EM, Schliephacke R, Breitenbach A, Breitkreutz J 2013. Drug-printing by flexographic printing technology — A new manufacturing process for orodispersible films. International Journal of Pharmaceutics 441(1-2):818-825.

42. McConnell EL, Fadda HM, Basit AW 2008. Gut instincts: explorations in intestinal physiology and drug delivery. International journal of pharmaceutics 364(2):213-226. 


\section{FIGURE LEGENDS}

FIGURE 1.Polymer Film Laminate concept. A Diagram of proposed continuous manufacture method to produce live bacterial cells dried directly onto pharmaceutical polymer film web. Cells mixed with lyoprotectants are spread onto a continuous web of enteric polymer film. B Alternative methods for laminating enteric formulations from film dried bacterial cells together with enteric polymer film spacers to produce PFL formulations.

FIGURE 2.Ambient temperature drying live $B$. breve onto pharmaceutical polymer films. (A) Individual drops of cells or evenly spread cell suspension were dried onto cast HPMC films at $20^{\circ} \mathrm{C}$ in a desiccator and viable cell recovery determined after release into buffered peptone. (B) $10 \mu \mathrm{L}$ drops of cells were dried onto films cast from either HPMC, Eudragit or Eudragit:EC blend $(50: 50 \mathrm{w} / \mathrm{w})$ and live cell recovery determined after release into buffered peptone expressed relative to the cell slurry volume prior to drying. Viable cell density prior to drying was measured from samples of cell slurry by plate counting and is indicated by dotted line. Each bar represents a single sample of cells dried onto film, and error bars indicate standard deviation of 6 replicate cell counts from each sample. Similar recovery after drying was observed in at least 3 independent experiments. *: $p<0.05$ vs HPMC; ns: not significant. In all groups a significant reduction in cell recovery was observed after drying $(p<0.05)$.

FIGURE 3.Acid permeability of enteric polymer films. Cast films of Eudragit or Eudragit:EC blend (50:50 w/w) were tested for swelling (A) and acid permeability in Franz diffusion cells (B) in SGF pH 2.0. A control dialysis membrane was used to confirm rapid acid diffusion to the acceptor chamber. (C) Dissolution of replicate samples of films was monitored in SIF pH 7.0. Data represent mean values and error bars indicate standard deviation $(\mathrm{n}=3)$.

FIGURE 4. Enteric polymer films can protect dried cells from acid. $B$. breve cells were dried at $26^{\circ} \mathrm{C}$ in a desiccator onto films of Eudragit or Eudragit:EC blend. Acid resistance was tested by comparing direct release of dried cells into SIF, to direct exposure to SGF, and to exposure of the enteric polymer film to acid on the opposite side to the dried cells, followed by release into SIF. Data are representative of at least 3 repeat experiments testing acid protection provided by enteric polymer films. *: $p<0.05$; ns: not significant. In all groups a significant reduction in cell recovery was observed after drying $(p<0.05)$.

FIGURE 5. Prototype enteric Polymer Film Laminate formulations protect and release dried live cells in gastrointestinal conditions. B. breve cells were dried at $26^{\circ} \mathrm{C}$ in a desiccator onto Eudragit and Eudragit:EC blend films and either kept as film pieces (left "Film") or made into PFL (right "PFL formulation"). Films were released directly into SIF to determine the postdrying viability (left). PFL formulations were exposed to simulated gastrointestinal conditions by immersion in SGF for 2 hours followed by transfer into SIF for 3 hours. Samples were taken at indicated times and viable cell recovery determined by plate counting. Each bar represents a single PFL formulation with the error bar indicating standard deviation of 6 replicate cell counts. Similar viable LBC recovery was observed in 4 different experiments comparing Eudragit with Eudragit:EC blend prototype PFL. Viable cell recovery was significantly reduced by drying compared to cell slurry before $(p<0.05)$, but no significant difference was seen after drying between Eudragit and Eudraget: EC blend films.

FIGURE 6. Dye is rapidly released from PFL with varying enteric polymer composition. PFL were made from Eudragit or Eudragit:EC blend films containing Water Blue dye, and the release kinetics followed in simulated gastrointestinal conditions. Results are representative of 3 repeats. 
FIGURE 7. Controlled delivery of probiotic and vaccine live bacterial cells from PFL in simulated gastrointestinal conditions. B. breve (A) or $S$. Typhimurium (B) cells were dried onto Eudragit films at $20^{\circ} \mathrm{C}$ in a desiccator and PFL were made with varying lamination method and adhesive (A) or film thickness (B). Unformulated films were released directly into SIF to determine post-drying viability. PFL were immersed in SGF for 2 hours followed by transfer into SIF and viable cell recovery determined at indicated timepoints. Each bar represents a single PFL formulation with the error bar indicating the standard deviation of 6 replicate cell counts of each sample. Similar recovery and kinetics were observed in 3 different experiments with $B$. breve and 2 with $S$. Typhimurium.

Figure

1

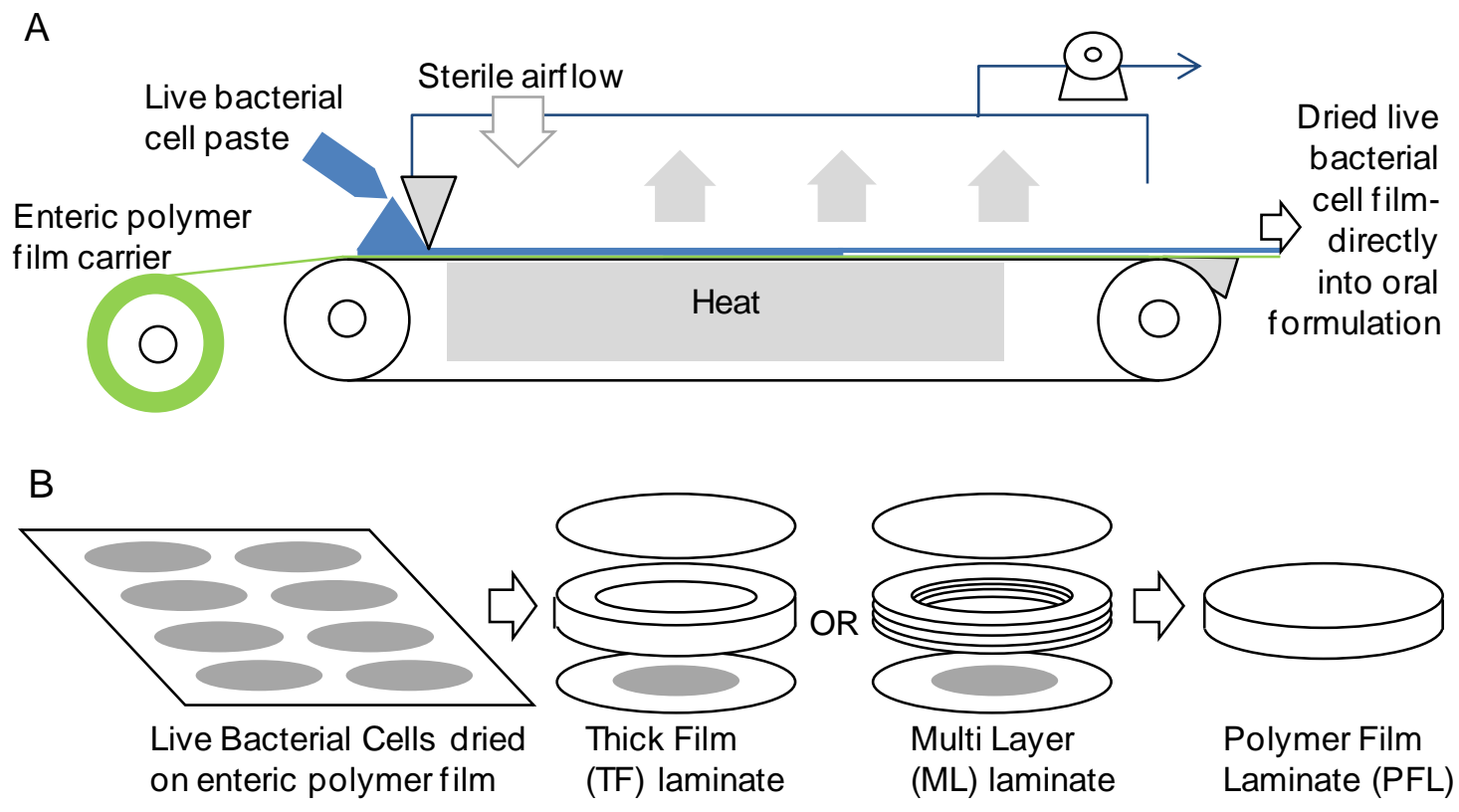

Figure 2
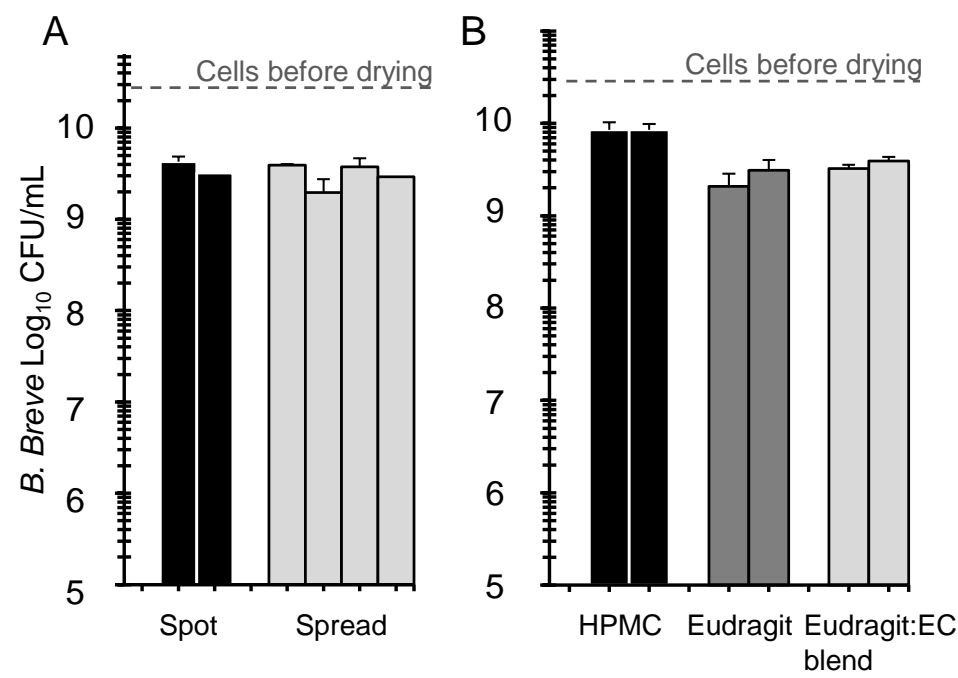
Figure 3
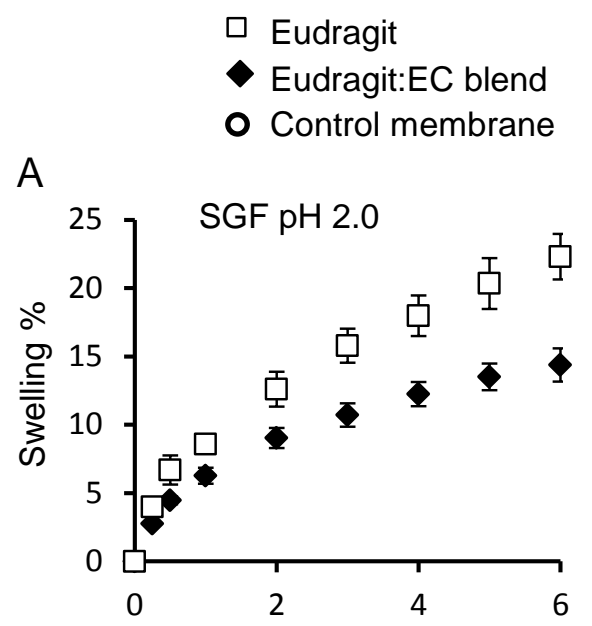

B

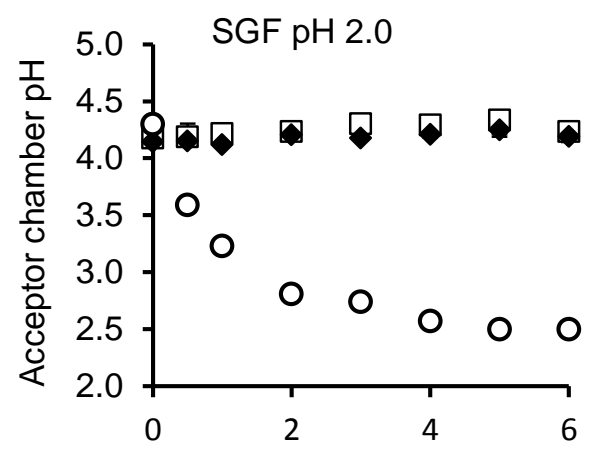

C
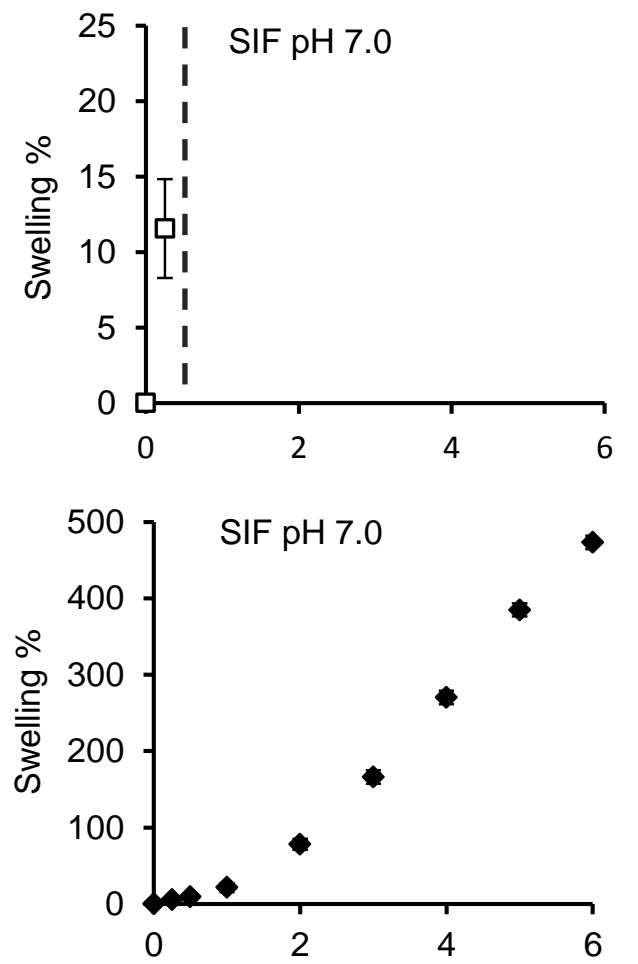

Time (hours) 
Figure 4
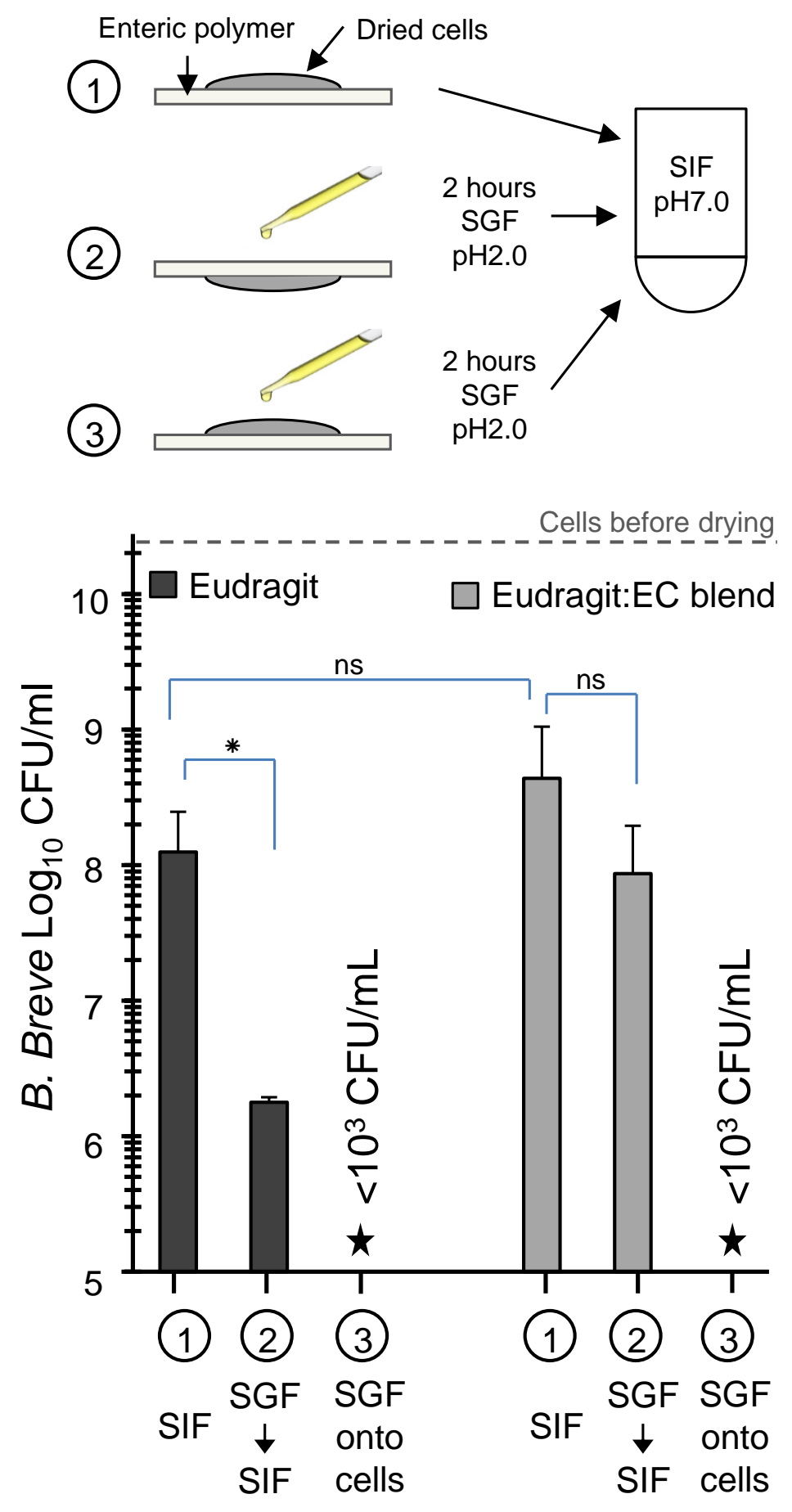
Figure 5
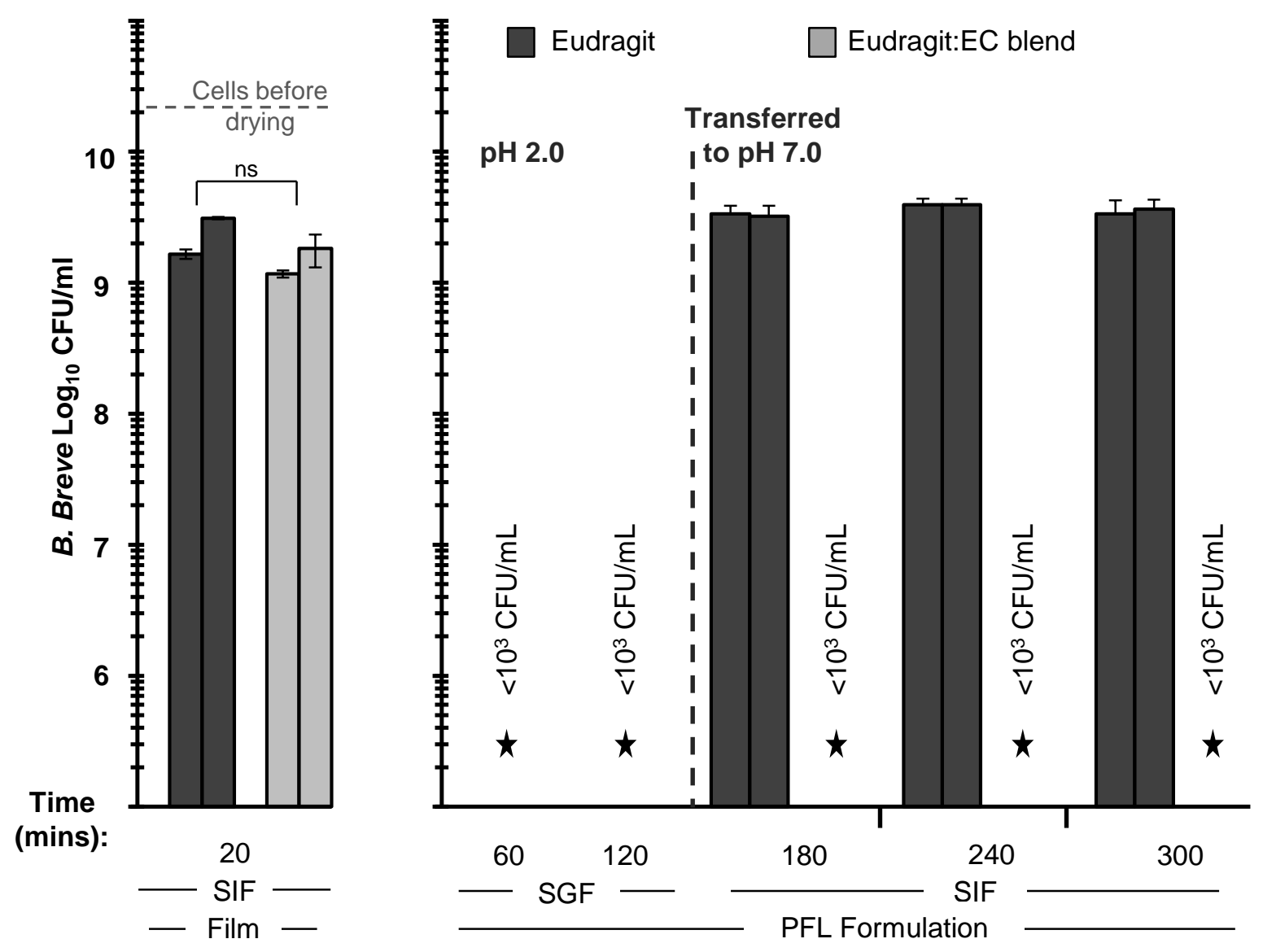

Figure 6

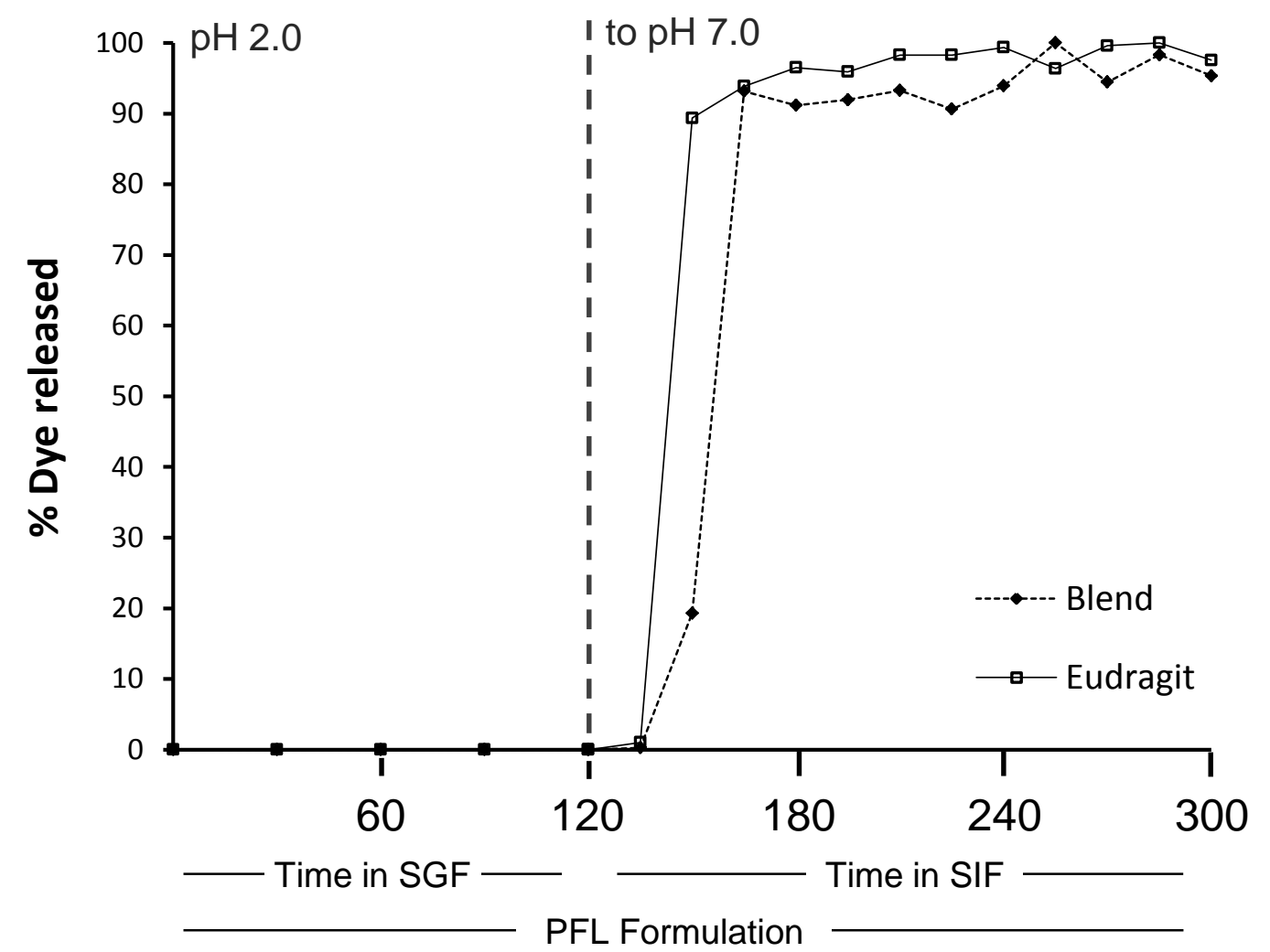




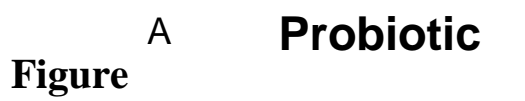

7
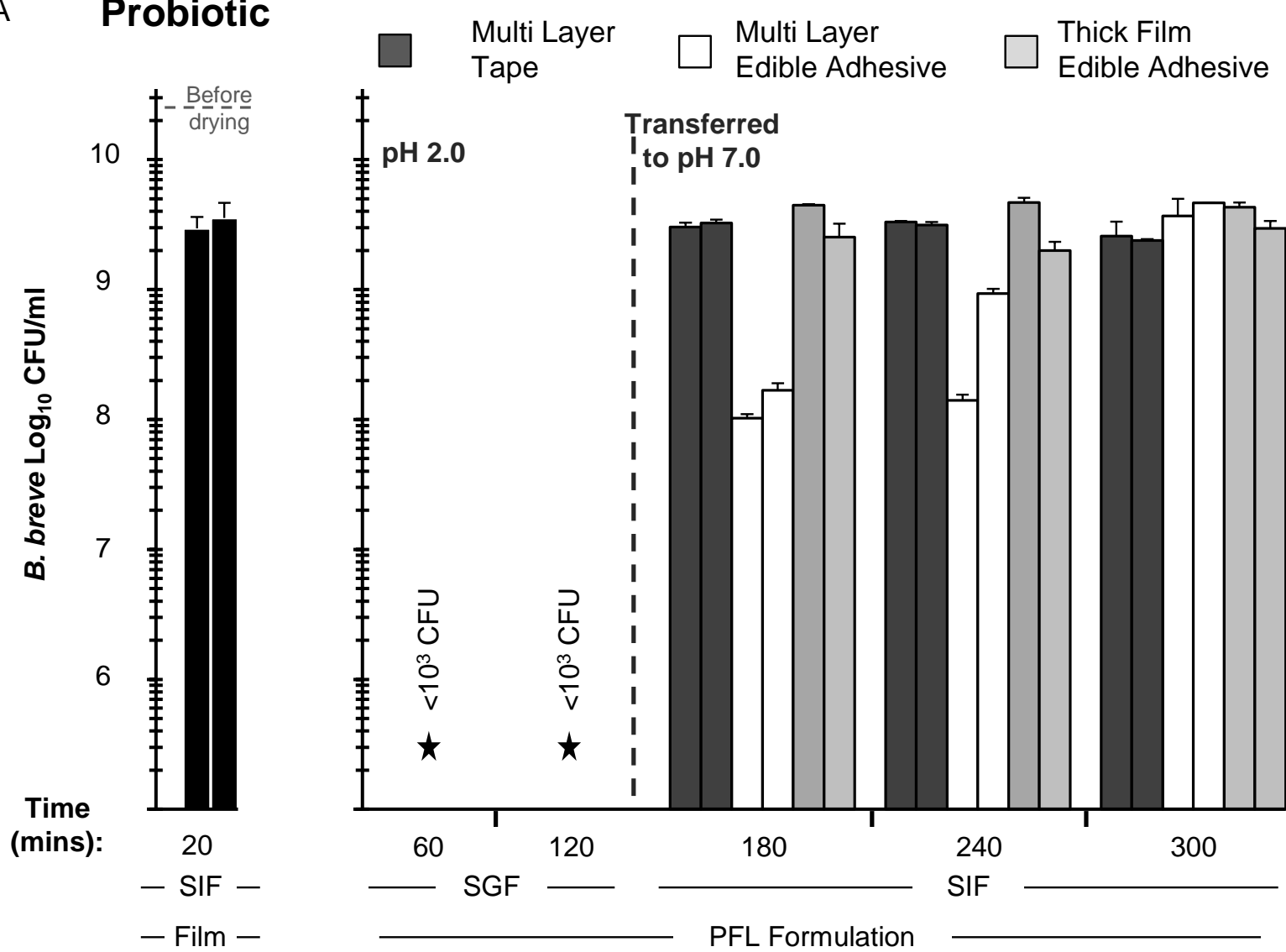

B

Oral vaccine

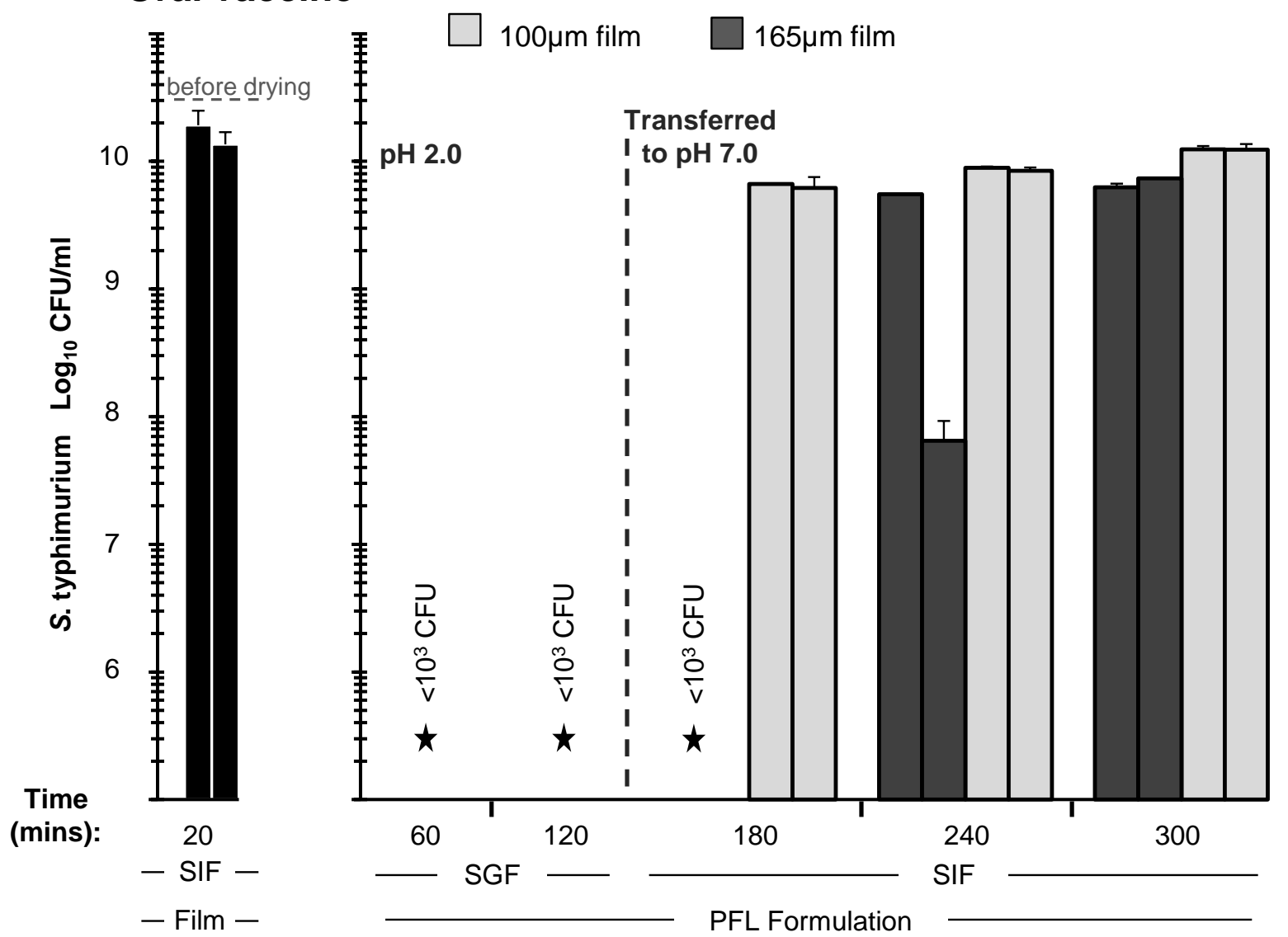

